\title{
A new replacement name for Eriobotrya integrifolia Aver. (Rosaceae)
}

\section{Ramalingam Kottaimuthu $^{1}$ (D) \& Muthuramalingam Jothi Basu² ${ }^{2}$ (D)}

Summary. A new species, Eriobotrya integrifolia Aver., described from Laos, is an illegitimate later homonym because the name is preoccupied by Eriobotrya integrifolia (Lindl.) Kurz. Therefore, Eriobotrya averyanovii Kottaim. is proposed as an avowed substitute for Averyanov's name.

Key Words. Homonym, Laos, Maleae, new name, nomenclature.

\section{Introduction}

Eriobotrya Lindl. (Lindley 1821: 96, 102) belongs to the tribe Maleae in the family Rosaceae (Kalkman 2004), the majority found in southwestern China (Yang et al. 2005). The recently described new species, Eriobotrya integrifolia Aver. (Averyanov et al. 2019) is illegitimate (according to Art. 53.1 of ICN, Turland et al. 2018) because it is a later homonym of Eriobotrya integrifolia (Lindl.) Kurz (1877: 304). Therefore, a new replacement name Eriobotrya averyanovii Kottaim. is proposed here.

\section{Nomenclature}

Eriobotrya averyanovii Kottaim., nom. nov.

http:/ /www.ipni.org/urn:lsid:ipni.org:names:77219677-1

Replaced synonym: Eriobotrya integrifolia Aver. in Averyanov et al., Pl. Diversity Fl. Veg. Hin Nam No: 119 (2019), nom. illeg., non Eriobotrya integrifolia (Lindl.) Kurz, J. Asiat. Soc. Bengal, Pt. 2, Nat. Hist. 45(4): 304 (1877). Type: Laos. Khammouane prov., Boualapha distr., Nong Seng village, southern sandstone slopes at summit of Phou Chuang (Poujeuang) Mt, 1000 - 1400 m a.s.l., 4 May 2018, L. Averyanov et al. AL 622 (LE01048253!).

\section{DISTRIBUTION. Laos.}

ETYMOLOGY. Named after Leonid Vladimirovich Averyanov discoverer of the species.

\section{Acknowledgement}

The financial support received from MHRD-RUSA 2.0 [F.24/51/2014-U, Policy (TNMulti-Gen), Department of Education Government of India] is gratefully acknowledged.

\section{References}

Averyanov, L., Nguyen, K. S. \& Maisak. T. (2019). Plant diversity, flora and vegetation of Hin Nam No Protected Area. Lambert Academic Publishing, Saarbrucken.

Kalkman, C. (2004). Rosaceae. In: K. Kubitzki (ed.), The Families and Genera of Vascular Plants. VI Flowering Plants-Dicotyledons Celastrales, Oxalidales, Rosales, Cornales, Ericales. Springer, Berlin.

Kurz, S. (1877). Contributions towards a knowledge of the Burmese flora. J. Asiat. Soc. Bengal Pt. 2, Nat. Hist. 45 (4): $204-310$.

Lindley, J. (1821). Observations on the natural group of plants called Pomaceae. Trans. Linn. Soc. London 13 (1): $88-106$.

Turland, N. J., Wiersema, J. H., Barrie, F. R., Greuter, W., Hawksworth, D. L., Herendeen, P. S., Knapp, S., Kusber, W.-H., Li, D.-Z., Marhold, K., May, T. W., McNeill, J., Monro, A. M., Prado, J., Price, M. J. \& Smith, G. F. (eds) (2018). International Code of Nomenclature for algae, fungi, and plants (Shenzhen Code) adopted by the Nineteenth International Botanical Congress Shenzhen, China, July 2017. Regnum Veg. 159. Koeltz Botanical Books, Glashütten.

Yang, X. H., Glakpe, K., Lin, S. Q., Hu, Y. L., He, Y., Nguyen, T. C. N., Liu, Y., Hu, G. B. \& Liu, C. M. (2005). Taxa of genus Eriobotrya plants around the world and specializing in Southeastern Asia. J. Fruit Sci. 22: $55-59$.

\section{Publisher's Note}

Springer Nature remains neutral with regard to jurisdictional claims in published maps and institutional affiliations.

\footnotetext{
Accepted for publication 6 September 2021. Published online 7 October 2021

1 Department of Botany, Alagappa University, Karaikudi, Tamil Nadu, 630 003, India. e-mail: kottaimuthu@yahoo.co.in

2 Department of Botany (DDE), Alagappa University, Karaikudi, Tamil Nadu, 630 003, India.
} 